\title{
Similarities and Differences Between Papal Discourses and Presidential Speeches: Wishes, Values, Scenarios, Spaces and Agents

\author{
David Maldavsky \\ dmaldavsky@gmail.com
} \\ Head of the Doctorate in Psychology and the Master in Helplessness People,
}

Chair of the Editor Staff of Subjetividad y procesoscognitivos, Universidad de CienciasEmpresariales y

Sociales, Buenos Aires, Argentina.

Sebastián Plut stplut@gmail.com

Teacher in the Doctorate in Psychology and the Master in Helplessness People,

Member of the Editor Staff of Subjetividad y procesoscognitivos, Universidad de CienciasEmpresariales y Sociales,

\section{ABSTRACT}

Buenos Aires, Argentina.

The paper details in the first place the frequency distributions in the analysis of wishes in words in papal speeches and then compares them with the frequency distributions in the analysis of wishes in words in presidential speeches. The differences detected between both analyses let us infer that words such as truth, love and beauty are more relevant in papal speeches, whereas the ideals of winning, justice and dignity prevail in presidential speeches. Moreover, there are differences between these speeches in terms of the kind of scenario narrated, the spatial concept, the colleagues, etc.

\section{Indexing terms/Keywords}

Words - papal discourse - presidential discourse - frequency distribution.

\section{Academic Discipline And Sub-Disciplines}

Psychology

\section{SUBJECTCLASSIFICATION}

Social-Psychology, Political Psychology

\section{TYPE (METHOD/APPROACH)}

Word analysis

\section{Council for Innovative Research}

Peer Review Research Publishing System

\section{Journal: Journal of Advances in Linguistics}

\author{
Vol 6, No 1, \\ editor@cirjal.com \\ www.cirjal.com, jaleditoronline@gmail.com
}




\section{INTRODUCTION}

This paper represents an advance in the development and application of the instruments of the David Liberman algorithm (DLA), especially the computer dictionary to analyze words and frequency distributions.

We will focus on the study of words in papal and presidential speeches. We will start by presenting the frequency distribution in the analysis of wishes in words in papal speeches, research which was unpublished until now. Then, we will compare the frequency distribution thus obtained with the frequency distributions in the analysis of wishes in words in presidential speeches, which we have already published. Following we will extract the conclusions belonging to the prevalence of certain wishes in one or the other kind of discourse and we will highlight other aspects of discourse in one of the other kind of speaker which are possibly inferred as existing from the aforementioned comparisons, and which include both kinds of scenes narrated, the spatial concept, the values, the colleagues, etc.

To do so, we will turn to the already mentioned dictionary and the corresponding frequency distributions as well as the narrative classification charts and some aspects of the scenes narrated. Our main objective is to compare papal discourses and presidential assumption speeches.

The study of discourses (in this case, political or religious) may have several uses. According to the researcher's objectives, it is preferable to study some of the analysis levels in detail. For example, the study of the argumentative strategies through which the speakers pretends to convince the recipient usually requires focusing on the acts of speech, for which the DLA also has specific instruments. Instead, the study of words can allow detecting wishes and hopes of the speaker as well as his concept of spaces, dominant characters and other kind of agents, as in this case. The studies on several analysis levels can be combined with a more complex approach allowing the detection of contradictory orientations in the same speaker.

\section{The Word Networks, Information Technology Instruments and the DLA Dictionary and Their Power Of Analysis}

There are several studies in the literature which have resorted to some information technology instrument to analyze the present signals networks, for example, in political discourse (Armony, 2005; Bolívar Ramírez, 2006; Calvet, 2008, among others). Likewise, there are different computer packages which usually include different types of processes: coding, indexing, lemmatization, network analysis, etc. Some of said computer programs are called KWOC ${ }^{1}$ and some other are called KWIC ${ }^{2}$ (see Bauer, 2003).

One of the problems that these computer programs have to solve was how to reduce the words in a text to an amount of concepts, each one of which has examples.

Every text has a distribution: some words have a very high incidence and some other appear very few times. The idea is to contract this to have very few concepts with a more interesting distribution (i.e., the concepts to which the words refer must be restricted and, at the same time, they must be comprehensive enough).

Beyond the diversity in studies, techniques and approaches, the different authors coincide in the importance of contributing empirical results on discourse and also in the analysis of the lexical frequencies allow developing a study on the production of meanings.

Usually the kind of operations done comprises the following:

- factorial analysis of correspondences: it builds the list of words and the frequency of use for each enunciator ${ }^{3}$;

- analysis of specific features: the computer program compares the speech of a politician with a database and identifies terms significantly overused and underused;

- co-occurrence analysis: it detects the lexical connections networks in the discourse ${ }^{4}$.

Many of the computer programs (such as ALCESTE) are lexicometrical instruments and lead to create files according to inductive and pragmatic criteria from semantic categories derived from the concrete situations in the study. For example, in the research done by Armony, for the aforementioned analysis of specific features, a one-and-a-half-million-word database was built, using over 800 speeches given by Juan Perón, RaúlAlfonsín, Carlos Menem and Néstor Kirchner.

The DLA program, however, is a dictionary, the files of which are compiled from preset categorizations used to move towards the study of concrete words. Accordingly, our proposal stems from a hypothetical deductive (Freudian) method. It is important to highlight that the poolability criteria to constitute each network correspond to their semantic value (wishes).

Each one of these levels of analysis using the David Liberman algorithm has their own instruments (a chart for the narratives, two charts for the phrase levels and the dictionary to analyze the word network). However, they all arise from the Freudian theory of wishes as a category system for discourse meaning. The wishes considered are seven: 
intrasomatic libido (IL), 2) primary oral $(\mathrm{O} 1), 3)$ secondary oral sadistic (O2), 4) primary anal sadistic (A1), 5) secondary anal sadistic (A2), 6) urethral phallic (UPH), and 7) genital phallic (GPH).

The DLA dictionary has seven files consisting in words, each one of which expresses a specific concept (each concept refers to the wishes conforming part of the category repertoire). Nevertheless, according to the semantic polyvalence that some words have, the DLA dictionary allows for each word to express more than one concept (it admits up to three options).

Each one of the seven files - corresponding to each one of the wished - comprises the following: a) word fragments, b) words, c) groups of words 5 .

As for the criterion to group words in each one of the files, Maldavsky refers that it derives from certain specifications: "1) certain affections (for example, apathy, futility, despair, boredom, hopelessness, pessimism, disgust), 2) certain motor performances (breathing, finger movements, facial expression, kicking, swaying, for example), 3) certain perceptions (for example, rhythms and frequencies, hits and vertigo, on the one hand, pinpoint and geometrical, on another hand, proximal and emotional, on still another hand, positional regarding hierarchies, on yet another hand, aesthetically harmonic or disharmonic, on a yet further hand), 4) certain scenes in a narrative, 5) certain conceptions of the ideal (winning, love, justice, dignity, beauty, for example) and representation-group, 6) certain temporal-spatial conceptions (for example, interplanetary space, intracorporeal space, circular space, stage type, labyrinthine or abysmal space, tiered space), 7) certain features of the agents (for example, the doubles: mirror image, shadow, spirit, placenta)" (2004a, p. 72).

It will have been noted that in different occasions we referred to not so much as "words" but to "network of signs". This is because, in order to determine the relevance of the language expressing a given wish in the level of words, the presence of a network is required and the presence of a single term is not enough.

Furthermore, it is habitual to find that word networks corresponding to several wishes coexist in the same discourse, which leads to question ourselves about the relationships among them: subordination, reinforcement, complementarity.

In the following chart we show some examples of words corresponding to the diverse wishes and part of their rationale.

\begin{tabular}{|c|c|c|}
\hline Wish & Examples of words & Rationale \\
\hline $\begin{array}{l}\text { Phallic } \\
\text { Genital }\end{array}$ & $\begin{array}{l}\text { Suffix "-ly" ("mente"), jewel, to give, } \\
\text { disgust, to adorn, skirt, to promise, to } \\
\text { mar, to shine, fascinated, famous, great, } \\
\text { impotent, incredible, etc. }\end{array}$ & $\begin{array}{l}\text { It implies the search for beautification, charms, } \\
\text { adornments, i.e., the aesthetic impact becomes } \\
\text { relevant by framing the self-image according to } \\
\text { the wishes of another. The form, the "how" is } \\
\text { stressed. }\end{array}$ \\
\hline $\begin{array}{l}\text { Phallic } \\
\text { Urethral }\end{array}$ & $\begin{array}{l}\text { To guide, to place, to locate, to get } \\
\text { accustomed, to accompany, to recede, } \\
\text { to flee, contagion, to get into, to } \\
\text { penetrate, to fear, to try, terms in } \\
\text { diminutive (use of little (suffix "ito")), } \\
\text { almost, half, little, etc. }\end{array}$ & $\begin{array}{l}\text { The attachment to routine, adventure, } \\
\text { disorientation (being lost), questions such as } \\
\text { "where" or "when" linked to the temporal-spatial } \\
\text { location are highlighted. }\end{array}$ \\
\hline $\begin{array}{l}\text { Secondary } \\
\text { Anal } \\
\text { Sadistic }\end{array}$ & $\begin{array}{l}\text { To correct, to think, to possess, to } \\
\text { subordinate, to have to, to order, doubt, } \\
\text { ritual, tradition, vice, clean, to oppose, } \\
\text { bad, no, but, because, although, } \\
\text { however, etc. }\end{array}$ & $\begin{array}{l}\text { Scenes of public oaths, institutionalized contexts, } \\
\text { hierarchies, order, attempts to dominate and } \\
\text { control reality from knowing concrete facts are } \\
\text { important. }\end{array}$ \\
\hline $\begin{array}{l}\text { Primary } \\
\text { Anal } \\
\text { Sadistic }\end{array}$ & $\begin{array}{l}\text { To abuse, to screw, traitor, to threaten, } \\
\text { weapon, crime, to confess, judge, to } \\
\text { provoke, to persuade, hero, etc. }\end{array}$ & $\begin{array}{l}\text { Terms linked to avenging struggles, humiliating } \\
\text { the other person, abuse, defeat, motor } \\
\text { impotence, etc. }\end{array}$ \\
\hline $\begin{array}{c}\text { Secondary } \\
\text { Oral }\end{array}$ & $\begin{array}{l}\text { To affect, to brighten, to crave, to regret, } \\
\text { guilt, to feel, sacrifice, sin, now, } \\
\text { impatience, to depress, etc. }\end{array}$ & $\begin{array}{l}\text { The terms allude to the scenes of sacrifice, } \\
\text { suffering which have to be endured, the } \\
\text { expression of feelings, love, family life, etc. }\end{array}$ \\
\hline $\begin{array}{c}\text { Primary } \\
\text { Oral }\end{array}$ & $\begin{array}{l}\text { To abstract, nobody, to deduce, to } \\
\text { decipher, idea, spirit, microscope, } \\
\text { extraterrestrial, essence, etc. }\end{array}$ & $\begin{array}{l}\text { It privileges abstract thought, the apparatus to } \\
\text { extract data and conclusions. It also involves } \\
\text { motor movements of the fingers and the tongue. }\end{array}$ \\
\hline $\begin{array}{l}\text { Intra- } \\
\text { Somatic } \\
\text { Libido }\end{array}$ & $\begin{array}{l}\text { To stun, vertigo, tension, to add, to hit, } \\
\text { accounts, to use drugs, to unburden, } \\
\text { money, etc. }\end{array}$ & $\begin{array}{l}\text { It emphasizes scenes corresponding to } \\
\text { economic levy or organic intrusions (i.e., } \\
\text { references to accounting and/or corporeal } \\
\text { statements carry weight). }\end{array}$ \\
\hline
\end{tabular}


The use of the dictionary has been enriched by complementing with other instruments, among which is remarkable to have different frequency distributions available which allow comparing the results of the analysis of a specific speech with the results of the studies on a bigger sample.

Similarly, the DLA includes other instruments with may widen the power of analysis with the computerized dictionary. Indeed, a recent study (Maldavsky and Argibay, 2015) has led to noticing that there is a high percentage of coincidences (84\%) among the results of the analysis of wishes in words and narratives and, therefore, it is possible to assert that, at least tentatively, that the study of wishes with the dictionary let us make inferences on other aspects of the speaker's speech, which includes the development of certain scenes and certain features within them (type of spatiality, type of value or ideal, type of agent, etc.). Find below a chart showing a sector of the scenes (Table I), consisting in the initial state in the narratives and a first transformation, the awakening of wishes. We also present a chart showing some features of said scenes (Table II).

Table I. Initial state and first transformation in the narrative for each wish

\begin{tabular}{|c|c|c|c|c|c|c|c|}
\hline $\begin{array}{c}\text { WISH } \\
\text { SCENE }\end{array}$ & $\begin{array}{l}\text { GENITAL } \\
\text { PHALLIC }\end{array}$ & $\begin{array}{l}\text { URETHRAL } \\
\text { PHALLIC }\end{array}$ & $\begin{array}{c}\text { SECONDARY } \\
\text { ANAL } \\
\text { SADISTIC }\end{array}$ & $\begin{array}{l}\text { PRIMARY } \\
\text { ANAL } \\
\text { SADISTIC }\end{array}$ & $\begin{array}{c}\text { SECONDARY } \\
\text { ORAL } \\
\text { SADISTIC }\end{array}$ & $\begin{array}{l}\text { PRIMARY } \\
\text { ORAL }\end{array}$ & $\begin{array}{l}\text { INTRA- } \\
\text { SOMATIC } \\
\text { LIBIDO }\end{array}$ \\
\hline Initial state & $\begin{array}{l}\text { Aesthetic } \\
\text { harmony }\end{array}$ & Routine & $\begin{array}{c}\text { Hierarchic } \\
\text { order }\end{array}$ & $\begin{array}{l}\text { Natural legal } \\
\text { equilibrium }\end{array}$ & Paradise & $\begin{array}{l}\text { Cognitive } \\
\text { peace }\end{array}$ & $\begin{array}{c}\text { Equilibrium of } \\
\text { tensions }\end{array}$ \\
\hline $\begin{array}{c}\text { First } \\
\text { transformation: } \\
\text { awakening of } \\
\text { wishes }\end{array}$ & $\begin{array}{l}\text { Wish for } \\
\text { aesthetic } \\
\text { completion }\end{array}$ & $\begin{array}{l}\text { Ambitious } \\
\text { wishes }\end{array}$ & $\begin{array}{l}\text { Wish to } \\
\text { dominate an } \\
\text { object in the } \\
\text { frame of a } \\
\text { public oath }\end{array}$ & Avenging wish & $\begin{array}{l}\text { Temptation } \\
\text { Expiation }\end{array}$ & $\begin{array}{l}\text { Abstract } \\
\text { cognitive } \\
\text { wish }\end{array}$ & $\begin{array}{l}\text { Speculative } \\
\text { wish }\end{array}$ \\
\hline
\end{tabular}

Table II. Main features of scenes for each wish

\begin{tabular}{|c|c|c|c|c|c|c|c|}
\hline & GPH & UPH & A2 & A1 & 02 & 01 & IL \\
\hline 1) Attributes & $\begin{array}{l}\text { Beauty } \\
\text { ugliness }\end{array}$ & $\begin{array}{l}\text { Dignity } \\
\text { indignity }\end{array}$ & $\begin{array}{l}\text { Order and } \\
\text { correction - } \\
\text { disorder and } \\
\text { incorrectness }\end{array}$ & $\begin{array}{l}\text { Abuser } \\
\text { abused }\end{array}$ & \begin{tabular}{|l|} 
Useful \\
useless
\end{tabular} & $\begin{array}{l}\text { Hyper-lucid } \\
\text { observer } \\
\text { object } \\
\text { observation } \\
\text { and } \\
\text { experimentatio } \\
n\end{array}$ & $\begin{array}{l}\text { Speculator - } \\
\text { object of } \\
\text { speculation }\end{array}$ \\
\hline 2) Ideal & Beauty & Dignity & Order & Justice & Love & Abstract truth & Winning \\
\hline 3) Helpers & $\begin{array}{l}\text { Adornments } \\
\text {, clothes, } \\
\text { etc., gifts } \\
\text { that } \\
\text { enhance } \\
\text { charm, } \\
\text { children as } \\
\text { decorative } \\
\text { objects (or } \\
\text { inversely, } \\
\text { which mar } \\
\text { the scene) }\end{array}$ & $\begin{array}{l}\text { Objects (cars, } \\
\text { horses, etc.) } \\
\text { which } \\
\text { increase the } \\
\text { potency or } \\
\text { accompany } \\
\text { the person } \\
\text { advancing } \\
\text { (compass, } \\
\text { map, copilot) } \\
\text { or linked to } \\
\text { chance and } \\
\text { accidents } \\
\text { while trying to } \\
\text { advance } \\
\text { (sorcerers, } \\
\text { witches and } \\
\text { their } \\
\text { respective } \\
\text { instruments of } \\
\text { power: crystal } \\
\text { ball, owl, } \\
\text { incantations, } \\
\text { etc.) }\end{array}$ & $\begin{array}{l}\text { Objects which } \\
\text { allow the } \\
\text { subject to } \\
\text { master } \\
\text { concrete } \\
\text { reality via } \\
\text { knowledge } \\
\text { (encyclopedia } \\
\text { etc.), via } \\
\text { cleanliness, } \\
\text { via } \\
\text { institutional } \\
\text { hierarchies } \\
\text { (statures, } \\
\text { contracts, son } \\
\text { as official at } \\
\text { the service of } \\
\text { administrative } \\
\text { domain), via } \\
\text { ceremonies } \\
\text { (sacred } \\
\text { objects, etc.) }\end{array}$ & $\begin{array}{l}\text { Objects } \\
\text { which allow } \\
\text { the subject } \\
\text { to attack or } \\
\text { avoid or } \\
\text { defend } \\
\text { himself } \\
\text { against } \\
\text { physical } \\
\text { aggression } \\
\text { involving the } \\
\text { alloplastic } \\
\text { muscular } \\
\text { compromise } \\
\text { (weapons, } \\
\text { spies, } \\
\text { informers, } \\
\text { accomplices } \\
\text {, trenches) }\end{array}$ & $\begin{array}{l}\text { Objects } \\
\text { given as } \\
\text { sacrifice } \\
\text { (objective } \\
\text { property } \\
\text { such as } \\
\text { material } \\
\text { possessions } \\
\text { subjective or } \\
\text { property as } \\
\text { such a a } \\
\text { time, effort, } \\
\text { affection, a } \\
\text { son) }\end{array}$ & 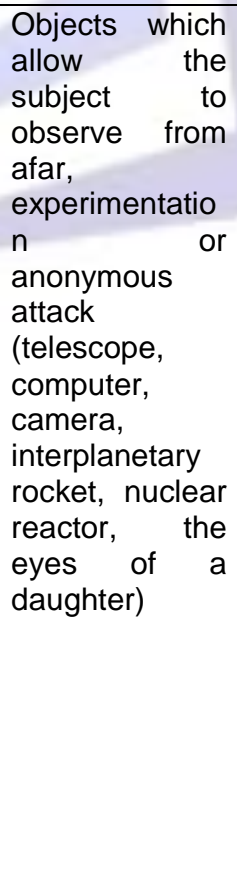 & $\begin{array}{l}\text { Objects } \\
\text { which allow } \\
\text { the subject to } \\
\text { obtain } \\
\text { economic } \\
\text { gain or } \\
\text { pleasure } \\
\text { (artificial } \\
\text { penis, erotic } \\
\text { dolls, } \\
\text { government } \\
\text { bonds, } \\
\text { securities, } \\
\text { merchandise } \\
\text {, the dowry } \\
\text { received by } \\
\text { the marriage } \\
\text { of a } \\
\text { daughter) }\end{array}$ \\
\hline
\end{tabular}




\begin{tabular}{|c|c|c|c|c|c|c|c|}
\hline $\begin{array}{l}\text { 4) Dominant } \\
\text { characters }\end{array}$ & Queen. & $\begin{array}{l}\text { Sorcerers, } \\
\text { oracles } \\
\text { orwizards }\end{array}$ & $\begin{array}{l}\text { School } \\
\text { directors and } \\
\text { other } \\
\text { institutional } \\
\text { leaders }\end{array}$ & \begin{tabular}{|l|} 
Political \\
leaders, etc.
\end{tabular} & $\begin{array}{l}\text { Household } \\
\text { mother }\end{array}$ & \begin{tabular}{|l|} 
Mystics, \\
philosophers
\end{tabular} & $\begin{array}{l}\text { Investors, } \\
\text { capitalists }\end{array}$ \\
\hline 5) Spaces & $\begin{array}{l}\text { Theater, } \\
\text { ballroom, } \\
\text { reception } \\
\text { hall }\end{array}$ & $\begin{array}{l}\text { Gorges, wide } \\
\text { open spaces, } \\
\text { closed spaces } \\
\text { (neighborhood } \\
\text {, club, bar) } \\
\text { open spaces, } \\
\text { heights, } \\
\text { depths }\end{array}$ & $\begin{array}{l}\text { With chain of } \\
\text { command: } \\
\text { churches, } \\
\text { schools }\end{array}$ & \begin{tabular}{|l} 
Battlefield, \\
jungle, \\
concrete \\
jungle
\end{tabular} & $\begin{array}{l}\text { Intimate } \\
\text { space } \\
\text { (kitchen, } \\
\text { bedroom, } \\
\text { hone), } \\
\text { cemetery }\end{array}$ & $\begin{array}{l}\text { Interplanetary } \\
\text { space, desert, } \\
\text { laboratory, } \\
\text { labyrinth, } \\
\text { virtual space }\end{array}$ & $\begin{array}{l}\text { Intracorporea } \\
\text { I space, } \\
\text { currency and } \\
\text { market } \\
\text { information } \\
\text { boards, stock } \\
\text { market, night } \\
\text { clubs with } \\
\text { bright lights } \\
\text { and } \\
\text { deafening } \\
\text { noises }\end{array}$ \\
\hline $\begin{array}{l}\text { 6) Dominant } \\
\text { motor } \\
\text { performance } \\
\mathrm{s}\end{array}$ & $\begin{array}{l}\text { Undulating } \\
\text { motor skills } \\
\text { - burst }\end{array}$ & $\begin{array}{l}\text { Penetrating } \\
\text { motor skills } \\
\text { avoidance } \\
\text { behavior }\end{array}$ & $\begin{array}{l}\text { Ritualized } \\
\text { motor skills, } \\
\text { obedient to } \\
\text { cultural } \\
\text { guidelines }\end{array}$ & $\begin{array}{l}\text { Motor skills } \\
\text { directed } \\
\text { towards } \\
\text { revenge, to } \\
\text { drive } \\
\text { another } \\
\text { crazy and to } \\
\text { preserve the } \\
\text { subject from } \\
\text { retaliation } \\
\text { and } \\
\text { violence of } \\
\text { another }\end{array}$ & $\begin{array}{l}\text { Motor skills } \\
\text { which } \\
\text { express the } \\
\text { affections }\end{array}$ & $\begin{array}{l}\text { Discreet motor } \\
\text { skills of the } \\
\text { eyes (reading, } \\
\text { playing } \\
\text { binocular } \\
\text { divergence), } \\
\text { the fingers } \\
\text { (sleight of } \\
\text { hand, typing), } \\
\text { the tongue and } \\
\text { the lips }\end{array}$ & $\begin{array}{l}\text { Unload and } \\
\text { tension } \\
\text { regulation } \\
\text { motor skills } \\
\text { (self- } \\
\text { soothing } \\
\text { procedures) }\end{array}$ \\
\hline
\end{tabular}

We have used these instruments productively to conduct studies in the psychosocial field (Maldavsky, 2001a, Maldavsky, et al., 2002; Plut, 2009a, 2010, 2011, 2012). On this occasion, we will study papal and presidential acceptance speeches equipped with these instruments.

\section{Procedures}

We will begin by showing the frequency distribution in the analysis of whishes in papal speeches, research which was unpublished until now (point 3). Then, in point 4, we will compare the frequency distribution thus obtained with the frequency distributions in the wish analysis in presidential speeches, which we have published previously (Maldavsky, 2013), and we will extract the conclusions belonging to the prevalence of certain wishes in one or the other kind of discourse. Lastly, we will show the inferences which is possible to produce from the aforementioned comparisons and which involve the kinds of scenes narrated, the spatial concept, the values, the colleagues, etc. (point 5).

\section{Frequency distribution of wishes in words in papal speeches}

To study the papal discourse, we analyze short of 70 speeches corresponding to Popes in the last 182 years. We have included several types of allocutions in the sample, especially homilies, encyclicals and speeches ${ }^{6}$ (Table III). 
Table III: Overview of papal texts studied

\begin{tabular}{|l|l|l|}
\hline Pope & Number of speeches & Years \\
\hline Gregory XVI & 7 & $1831-1846$ \\
\hline Pius IX & 3 & $1846-1878$ \\
\hline Leo XIII & 3 & $1878-1903$ \\
\hline Pius X & 6 & $1903-1914$ \\
\hline Benedict XV & 3 & $1914-1922$ \\
\hline Pius XI & 3 & $1922-1939$ \\
\hline Pius XII & 12 & $1939-1958$ \\
\hline John XXIII & 9 & $1958-1963$ \\
\hline Paul VI & 7 & $1963-1978$ \\
\hline John Paul I & 4 & 1978 \\
\hline John Paul II & 4 & $1978-2005$ \\
\hline Benedict XVI & 2 & $2005-2013$ \\
\hline Francis & 3 & 2013 \\
\hline Total & 66 & \\
\hline
\end{tabular}

Here is the frequency distribution corresponding to these speeches (Table IV):

Table IV. Frequency distribution of wishes in papal speeches Statistical

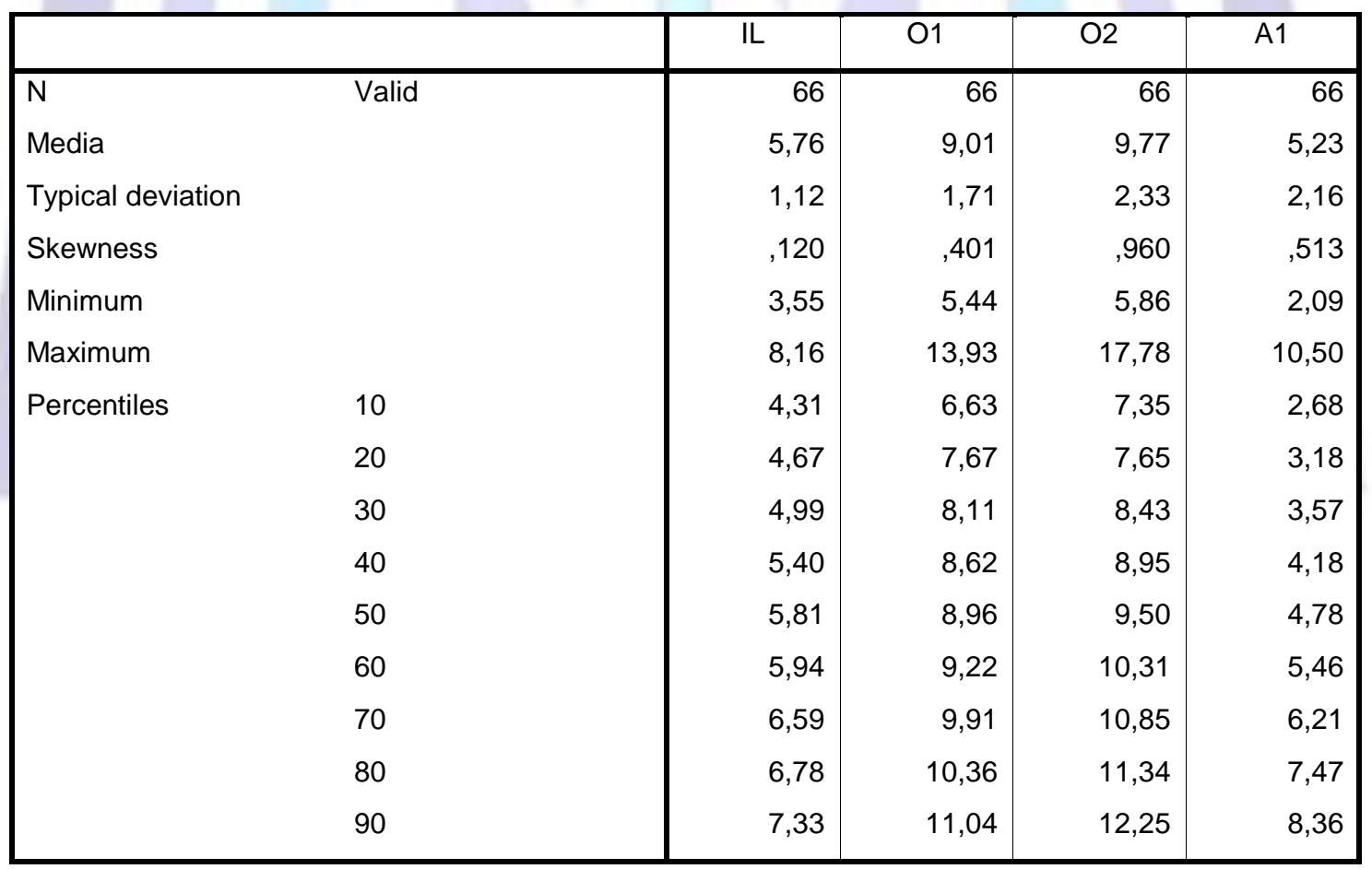


Statistical

\begin{tabular}{|c|c|c|c|c|}
\hline & & $\mathrm{A} 2$ & UPH & $\mathrm{GPH}$ \\
\hline $\mathrm{N}$ & Valid & 66 & 66 & 66 \\
\hline Media & & 35,93 & 11,92 & 22,37 \\
\hline Typical devi & & 4,70 & 2,18 & 3,64 \\
\hline Skewness & &,- 071 & ,450 & ,461 \\
\hline Minimum & & 26,79 & 7,14 & 15,89 \\
\hline Maximum & & 47,26 & 17,76 & 31,74 \\
\hline Percentiles & 10 & 29,13 & 9,08 & 17,70 \\
\hline & 20 & 32,16 & 10,20 & 19,28 \\
\hline & 30 & 33,33 & 10,63 & 20,13 \\
\hline & 40 & 34,45 & 10,79 & 20,71 \\
\hline & 50 & 35,69 & 11,54 & 21,79 \\
\hline & 60 & 37,65 & 12,23 & 23,42 \\
\hline & 70 & 39,36 & 12,85 & 24,46 \\
\hline & 80 & 40,32 & 13,98 & 25,51 \\
\hline & 90 & 41,52 & 14,86 & 27,72 \\
\hline
\end{tabular}

\section{Comparison between papal and presidential speeches: samples, procedures and results}

The following chart shows, for each wish, the percentiles corresponding to the two kinds of discourse, papal and presidential (Table V):

Table V. Comparisons between the frequency distributions in papal and presidential speeches

\begin{tabular}{|c|c|c|c|c|c|c|c|c|}
\hline Perc. & \multicolumn{2}{|c|}{ IL } & \multicolumn{3}{c|}{ O1 } & \multicolumn{2}{c|}{ A1 } \\
\hline & $\begin{array}{c}\text { Papal } \\
\text { speech }\end{array}$ & $\begin{array}{c}\text { Presidential } \\
\text { speech }\end{array}$ & $\begin{array}{c}\text { Papal } \\
\text { speech }\end{array}$ & $\begin{array}{c}\text { Presidential } \\
\text { speech }\end{array}$ & $\begin{array}{c}\text { Papal } \\
\text { speech }\end{array}$ & $\begin{array}{c}\text { Presidential } \\
\text { speech }\end{array}$ & $\begin{array}{c}\text { Papal } \\
\text { speech }\end{array}$ & $\begin{array}{c}\text { Presidential } \\
\text { speech }\end{array}$ \\
\hline 10 & 4,31 & 5,51 & 6,63 & 6,45 & 7,35 & 7,53 & 2,68 & 5,60 \\
\hline 20 & 4,67 & 6,91 & 7,67 & 6,74 & 7,65 & 7,83 & 3,18 & 5,97 \\
\hline 30 & 4,99 & 7,17 & 8,11 & 6,98 & 8,43 & 8,00 & 3,57 & 6,56 \\
\hline 40 & 5,40 & 7,58 & 8,62 & 7,41 & 8,95 & 8,59 & 4,18 & 7,02 \\
\hline 50 & 5,81 & 7,95 & 8,96 & 7,55 & 9,50 & 8,82 & 4,78 & 7,37 \\
\hline 60 & 5,94 & 8,16 & 9,22 & 7,76 & 10,31 & 9,09 & 5,46 & 7,79 \\
\hline 70 & 6,59 & 8,56 & 9,91 & 7,90 & 10,85 & 9,48 & 6,21 & 8,19 \\
\hline 80 & 6,78 & 8,79 & 10,36 & 8,52 & 11,34 & 9,86 & 7,47 & 8,96 \\
\hline 90 & 7,33 & 9,94 & 11,04 & 9,34 & 12,25 & 10,42 & 8,36 & 9,56 \\
\hline
\end{tabular}




\begin{tabular}{|c|c|c|c|c|c|c|}
\hline Perc. & \multicolumn{2}{|c|}{ A2 } & \multicolumn{2}{c|}{ UPH } & \multicolumn{2}{c|}{ GPH } \\
\hline & $\begin{array}{c}\text { Papal } \\
\text { speech }\end{array}$ & $\begin{array}{c}\text { Presidential } \\
\text { speech }\end{array}$ & $\begin{array}{c}\text { Papal } \\
\text { speech }\end{array}$ & $\begin{array}{c}\text { Presidential } \\
\text { speech }\end{array}$ & $\begin{array}{c}\text { Papal } \\
\text { speech }\end{array}$ & $\begin{array}{c}\text { Presidential } \\
\text { speech }\end{array}$ \\
\hline 10 & 29,13 & 32,17 & 9,08 & 11,25 & 17,70 & 16,07 \\
\hline 20 & 32,16 & 34,05 & 10,20 & 11,87 & 19,28 & 16,89 \\
\hline 30 & 33,33 & 34,74 & 10,63 & 12,19 & 20,13 & 17,47 \\
\hline 40 & 34,45 & 35,75 & 10,79 & 12,67 & 20,71 & 17,90 \\
\hline 50 & 35,69 & 36,24 & 11,54 & 12,86 & 21,79 & 18,83 \\
\hline 60 & 37,65 & 36,81 & 12,23 & 13,20 & 23,42 & 19,38 \\
\hline 70 & 39,36 & 37,52 & 12,85 & 13,88 & 24,46 & 19,81 \\
\hline 80 & 40,32 & 38,55 & 13,98 & 14,86 & 25,51 & 21,00 \\
\hline 90 & 41,52 & 40,52 & 14,86 & 15,65 & 27,72 & 21,73 \\
\hline
\end{tabular}

It was analyzed whether there were differences in the diverse wishes between a sample of papal speeches $(N=65)$ and a sample of presidential speeches $(N=56)$. One of the 66 papal discourses was not included because of its atypical characteristics. To do the calculation we use the t of Student for independent samples and the Levene test was used to calculate the equality of variances.

In the Levene test for equality of variance significant differences were obtained for O2; A1; A2; UF and GF. For these cases, the $t$ Test was calculates without supposing equal variances. In the rest of the wishes, equal variances were observed.

- $\quad$ IL: $F(1,119)=2,050 ; p=.155$

- O1: $F(1,119)=3,460 ; p=.065$.

- $\quad$ O2: $F(1,119)=15,786 ; p<.001$.

- $A 1: F(1,119)=6,403 ; p=.013$.

- $\quad A 2: F(1,119)=16,271 ; p<.001$.

- UPH: $F(1,119)=5,162 ; p=.025$.

- $\mathrm{GPH}: \mathrm{F}(1,119)=14,839 ; \mathrm{p}<.001$.

The values obtained for the papal and presidential speeches comparison were the following (in all the cases the significance is for two tails):

- IL: $\mathrm{t}(119)=-8,766 ; \mathrm{p}<.001$

- $\quad 01: \mathrm{t}(119)=4,716 ; \mathrm{p}<.001$

- O2: $t(97.490)=2,870 ; p=.005$

- $\quad A 1: t(118.479)=-6,272 ; p<.001$

- $\quad$ 2: $t(111.354)=, 176 ; p=.861$

- UPH: $t(116.408)=-3,585 ; p<.001$

- $\quad$ GPH: $t(109.618)=6,327 ; p<.001$

We found significant differences between papal speeches and presidential speeches in all the wishes, except in A2 (presidential media $=36.05$ and papal media $=35.92$ ) where no significant differences were found:

- IL: papal speeches have values lower in IL than presidential speeches (papal media $=5.78$ vs. presidential media $=7.90$ ). The difference was -2.12 and the confidence intervals at $95 \%$ for the difference were between -2.59 and - 1.64. On the other hand, the size of the effect is big, the typified difference was calculated by the $d$ of Cohen: $d=1.60$; which would equal an explained variance percentage of $38.88 \%$.

- $\quad$ 1: papal speeches have higher values in 01 than presidential speeches (papal media $=8.93$ vs. presidential media $=7.65$ ). The difference was 1.28 and the confidence intervals at $95 \%$ for the difference were between .74 and 1.82. On the other hand, the size of the effect is average, the typified difference was calculated by the $d$ of Cohen: $d=.860$; which would equal an explained variance percentage of $15.53 \%$.

- $\quad$ O2: papal speeches have higher values in $\mathrm{O} 2$ than presidential speeches (papal media $=9.79$ vs. presidential media $=8.84$ ). The difference was .95 and the confidence intervals at $95 \%$ for the difference were between .29 and 1.60. On the other hand, the size of the effect is average, the typified difference was calculated by the $d$ of Cohen: $d=.523$; which would equal an explained variance percentage of $6.37 \%$ 
- A1: papal speeches have lower values for $\mathrm{A} 1$ than presidential speeches (papal media $=5.26$ vs. presidential media $=7.49$ ). The difference was -2.23 and the confidence intervals at $95 \%$ for the difference were between 2.93 and -1.51 . On the other hand, the size of the effect is big, the typified difference was calculated by the $d$ of Cohen: $d=1.14$; which would equal an explained variance percentage of $24.42 \%$.

- UPH: papal speeches have lower values in UPH than presidential speeches (papal media $=11.95 \mathrm{vs}$. presidential media $=13.19$ ). The difference was -1.24 and the confidence intervals at $95 \%$ for the difference were between - 1.93 and - .56. On the other hand, the size of the effect is moderate, the typified difference was calculated by the $d$ of Cohen: $d=.654$; which would equal an explained variance percentage of $9.61 \%$.

- GPH: papal speeches have higher values in GPH than presidential speeches (papal media = 22.36 vs. presidential media $=18.88$ ). The difference was 3.48 and the confidence intervals at $95 \%$ for the difference were between 2.39 and 4.61 . On the other hand, the size of the effect is big, the typified difference was calculated by the $d$ of Cohen: $d=1.15$; which would equal a variance percentage of $24.74 \%$.

It should be pointed out that if the significance had been adjusted to the amount of tests run (seven), the significance value equivalent to .05 would have been $p=.007$, so that all the significant results would have continue to be so.

To sum up, significant differences were found between papal speeches and presidential speeches in six of the seven wishes: IL, GPH, A1, O1, FU, O2 (in this order of importance according to the size of the effect). In the case of the IL, A1 and $\mathrm{GPH}$, the higher values correspond to the presidential speeches, whereas in $\mathrm{GPH}, \mathrm{O} 1$ and $\mathrm{O} 2$ the greater values correspond to papal speeches.

\section{Conclusions}

Although it will be necessary to apply these results to the analysis of concrete speeches, it is possible to extract a global conclusion from them. To do so, we shall resort to Tables I and II, in which the scenes of the narratives and other of their features are shown.

Indeed, the presence of higher values for wishes $01, \mathrm{O} 2$ and GPH in papal discourse in comparison with presidential discourse allows to assume that in the first one ideals such as truth, love and beauty are more relevant. Conversely, the higher percentiles for wishes LI, A1 and UPH in presidential discourse lead to infer that the ideals of winning, justice and dignity have more emphasis.

Besides this privilege of given values or ideals, it may be that other features of the scenes (such as the type of leader, the kind of collaborator, the sort of space) will also have major prevalence in one kind of speech or the other. For example, in papal speeches it seems to prevail a reference to interstellar, transcendental spaces, as well as a reference to intimate, familial spaces, whereas in presidential speeches, the space combines the scene of market and banking experiences with the space of battles for some vindication and the leading characters are, for the Popes, mystics, philosophers, combined with household mothers, whereas for presidential speeches, the leading character combines investors and capitalists with other political leaders.

Furthermore, it should be noted that $\mathrm{A} 2$ has a similar weight in this and that kind of discourse and, therefore, it may be that the corresponding speakers coincide in terms of value, the sort of leader, the kind of space, etc. The value is the order, the heads are institutional leaders and the kind of specialty is that one with the higher or lesser value in the stepladder of an organization.

\section{REFERENCES}

[1] Armony, V.; (2005) "Aportes teórico-metodológicos para el estudio de la producción social de sentido a través del análisis del discurso presidencial", Rev. Argentina de Sociología, № 4.

[2] Bauer, M.; (2003) "Análisis de textos asistidos con programas computacionales", Rev. Subjetividad y procesos cognitivos, $\mathrm{N}^{\circ} 3$, UCES.

[3] Bolívar Ramírez, I.; (2006) Discursos emocionales y experiencias de la política: las FARC y las AUC en los procesos de negociación del conflicto (1998-2005), Ed. Uniandes.

[4] Calvet, L.J.; (2008) Les mots de Nicolas Sarkozy, Ed. Seuil.

[5] Freud, S.; (1901) Psicopatología de la vida cotidiana, O.C., AE, T. VI.

[6] Freud, S.; (1915) Pulsiones y destinos de pulsión, O.C., Vol. XIV, AE.

[7] Lahlou, S.; (1998) Pensermanger. Alimentation et représentations sociales, PressesUniversitaires de France (PUF).

[8] Maldavsky, D.; (1999) Lenguajes, pulsiones, defensas, Ed. Nueva Visión.

[9] Maldavsky, D.; (2001a) Análisis computacional del lenguaje desde la perspectiva psicoanalítica, en CD-Rom.

[10] Maldavsky, D.; (2001b) "Análisis computacional del discurso desde la perspectiva psicoanalítica”, Rev. Científica de UCES, Vol. 5, № 1.

[11] Maldavsky, D.; (2002) "Lenguajes del erotismo, cosmovisiones y periodismo político", en Actualidad Psicológica, Año XXVII, Nro. 296.

[12] Maldavsky, D.; (2004a) La investigación psicoanalítica del lenguaje, Ed. Lugar. 
[13] Maldavsky, D.; (2004b) Un diccionario computarizado para la investigación del discurso desde la perspectiva psicoanalítica, inédito.

[14] Maldavsky, D., et al.; (2002) "Análisis computacional del discurso periodístico con un enfoque psicoanalítico. Contribuciones a la psicología política", Revista del Instituto de Investigaciones, UBA, Año 7, № 3.

[15] Maldavsky, D., et al.; (2006) "Estudio sobre el Diccionario computarizado del ADL: revisión y modificaciones", IV Jornada de Actualización del Algoritmo David Liberman (IAEPCIS-UCES).

[16] Maldavsky, D., et al.; (2013) ADL. Un instrumento para la evaluación de los deseos y las defensas en el discurso, Ed. Paidós.

[17] Maldavsky, D., y Argibay, J. C. (2015), "Comparación entre las aplicaciones de dos distribuciones de frecuencias (en las palabras y en los relatos) del algoritmo David Liberman (ADL)", inédito.

[18] Mergenthaler, E. y Bucci, W.; (1993) "Computer-assisted procedures for analyzing verbal data in psychotherapy research", Paper presented at the $24^{\text {th }}$ Annual International Meeting of the Society for Psychotherapy Research, Pittsburgh, PA.

[19] Plut, S.; (2010) "Aplicación del Diccionario ADL en la investigación psicosocial, con especial énfasis en el análisis del discurso político", Revista Subjetividad y procesos cognitivos, Vol. 14, № 2, UCES.

[20] Plut, S.; (2011) "Redes de palabras en discursos de asunción de la Presidencia de la Nación", Aproximación al análisis de datos cualitativos, Ed. Universidad del Aconcagua.

[21] Plut, S.; (2012) Psicoanálisis del discurso político, Ed. Lugar.

[22] Plut, S.; (2013a) "La configuración del enemigo. Continuidad y ruptura entre George W. Bush y Barack Obama", Actualidad Psicológica, № 415.

[23] Plut, S.; (2013b) "Estudio comparativo de dos diarios que informan sobre un mismo suceso político", en Revista Subjetividad y procesos cognitivos, Vol. $17 \mathrm{~N}^{\circ} 2$, UCES.

[24] Plut, S.; (2014a) "El ocaso de un dictador. Análisis de un reportaje a Jorge R. Videla", Linguagem\&Ensino, Vol. 17, $N^{\circ} 1$, Pelotas, Brasil.

[25] Plut, S.; (2014b) "El sentimiento de inseguridad en la opinión pública", Revista Subjetividad y procesos cognitivos, Vol. $18, \mathrm{~N}^{\circ} 2$.

\section{AUTHORS' BIOGRAPHY}

\section{David Maldavsky}

Ph. Doctor Degree. He is the founder of the Doctorate in Psychology and the Master in Helplessness People and the journal Subjetividad y procesoscognitivos, Universidad de CienciasEmpresariales y Sociales, Buenos Aires, Argentina. He creates a method of research of the linguistic manifestations named David Liberman Algorithm (DLA).

\section{Sebastián Plut}

Ph. Doctor Degree, he investigates on the issue of Political Psychology, mostly in the field of the analysis of the discourse. 